\title{
SOSIALISASI GERAKAN MEMASYARAKATKAN MAKAN IKAN (GEMARIKAN) PADA SISWA SEKOLAH DASAR DI ACEH BARAT
}

\section{SOCIALIZATION GEMARIKAN IN BASIC SCHOOL STUDENTS IN WEST ACEH}

\author{
Zulfadhli $^{1}$ Rinawati $^{2}$ \\ ${ }^{1}$ Program Studi Akuakultur, Fakultas Perikanan dan IImu Kelautan, Universitas Teuku Umar \\ ${ }^{2}$ Program Studi Kesehatan Masyarakat, Fakultas Kesehatan Masyarakat, Universitas Teuku Umar \\ Korespondensi : zulfadhli@utu.ac.id
}

\begin{abstract}
ABSTRAK
Gerakan memasyarakatkan makan ikan (Gemarikan) merupakan program pemerintah yang diinisiasi oleh Kementrian Kelautan dan Perikanan (KKP RI) yang bertujuan memotivasi masyarakat untuk gemar makan ikan. Dalam ikan terdapat omega-3, EFA, dan DHA yang diperlukan untuk perkembangan otak. Anak-anak sejak dini sangat di sarankan mengkonsumsi ikan agar menjadi lebih sehat, cerdas dan kuat. Kegiatan ini dilaksanakan atas dasar siswa masih rendah minat mengkonsumsi ikan dan tidak mengetahui manfaatnya. Sosialisasi Gemarikan dilaksanakan di sekolah dasar negeri kuala bubon kecamatan samatiga kabupaten Aceh Barat. Metode yang dilaksanakan dengan ceramah dan bermain game ikan. Materi yang disampaikan yaitu: jenis-jenis ikan konsumsi, manfaat dan pentingnya kosumsi ikan, dan tip memilih ikan segar. Siswa sangat senang dan memperhatikan apa yang disampaikan dengan harapan setelah kegiatan ini selesai minat konsumsi ikan meningkat.
\end{abstract}

Kata kunci: sosialisasi, gemarikan, siswa, aceh barat

\begin{abstract}
Gemarikan is a government program initiated by the Ministry of Maritime Affairs and Fisheries (KKP RI) which aims to motivate people to like to eat fish. In fish there are omega-3s, EFAs, and DHA which are needed for brain development. Early childhood is strongly advised to consume fish to be healthier, smarter and stronger. This activity is carried out on the basis of students still low interest in consuming fish and do not know the benefits. Gemarikan socialization was carried out at the primary school in Kuala Lumpur district of Samatiga, West Aceh district. The method is carried out by lectures and playing fish games. The material presented was: types of consumption fish, benefits and importance of fish consumption, and tips on choosing fresh fish. Students are very happy and pay attention to what is conveyed in the hope that after this activity has finished interest in increasing fish consumption.
\end{abstract}

Key word: socialization, gemarikan, students, West Aceh

\section{PENDAHULUAN \\ Latar Belakang}

Kebutuhan protein terutama protein hewani bagi masyarakat untuk hidup sehat sesuai dengan anjuran para ahli gizi sampai saat ini masih merupakan masalah. Dalam usaha penyediaan sumber protein tersebut, ternyata sektor perikanan merupakan penyumbang lebih dari $3 / 4$ jumlah protein hewani yang dikonsumsi rakyat Indonesia. Konsumsi ikan merupakan suatu keadaan dimana setiap manusia mengkonsumsi ikan dalam jangka waktu satu tahun yang dinyatakan dengan $\mathrm{kg}$ ikan/kapita/tahun. Biasanya untuk masing-masing daerah tingkat konsumsi ikan ini akan berbeda satu sama lain. Begitu juga dengan masing-masing negara. Konsumsi 
ikan masyarakat Indonesia terbilang masih rendah, dengan rata-rata tingkat konsumsinya $41 \mathrm{~kg} / \mathrm{kapita} / \mathrm{tahun}$. Keadaan tersebut masih jauh bila dibandingkan dengan negara Malaysia, Singapura dan Jepang. Tingkat konsumsi ikan di Malaysia mencapai 70 kg/kapita/tahun, Singapura 80 kg/kapita/tahun dan Jepang 100 kg/kapita/tahun (Detik.com, 2017).

Rendahnya tingkat konsumsi ikan masyarakat Indonesia disebabkan oleh beberapa aspek seperti: a). Selera, Bau dan rasa amis yang ditimbulkan, b). Ikan tidak tersedia secara merata di setiap daerah, karena lokasi yang jauh dari sumber ikan, c). produk olahan ikan masih sangat rendah, karena pengolahan dilakukan tidak sesuai standard dan kurang hygiene.

Ikan mempunyai kandungan gizi dan nutrisi yang bermanfaat bagi kecerdasan dan kesehatan tubuh. Budaya konsumsi ikan yang tinggi oleh masyarakat Jepang telah membuktikan peningkatan kualitas kesehatan dan kecerdasan anak-anak (Nilawati, dkk, 2006). Menurut Devore (2009), ikan mengandung asam lemak tak jenuh (omega3), EPA (eicosapentaenoic acid) dan DHA (docosahexaenoic acid), yang sangat penting bagi fungsi dan struktur otak.

Konsumsi ikan yang tinggi selain memberikan manfaat bagi tubuh kita, juga menguragi ketergantungan konsumsi daging (sapi/ayam) yang mahal dan dapat membantu mensejahterakan nelayan. Atas pertimbangan tersebut pemerintah melalui Kementrian Kelautan dan Perikanan (KKP) RI membuat program gerakan memasyarakatkan makan ikan yang disingkat dengan Gemarikan. Gemarikan merupakan gerakan moral yang memotivasi mengkonsumsi ikan agar terbentuk anak bangsa yang sehat, cerdas dan kuat. Memberikan pengetahuan dan informasi bagi siswa sekolah dasar merupakah langkah yang baik untuk memberikan kesadaran dan motivasi akan manfaat konsumsi ikan.

\section{Permasalahan}

1. Rendahnya tingkat konsumsi ikan dikalangan anak sekolah

2. Rendahnya pemahaman terkait kandungan gizi yang berasal dari ikan dan manfaat mengkonsumsi ikan segar

3. Beberapa orang menganggap makan ikan akan menimbulkan bau amis

\section{Tujuan kegiatan}

1. Membangun kesadaran gizi individu agar gemar mengkonsumsi ikan

2. Memberikan informasi dan pengetahuan kepada siswa tentang asupan gizi yang berasal dari ikan dan manfaatnya 


\section{METODELOGI}

\section{Tempat dan Waktu}

Sosialisasi dilaksanakan pada tanggal 02 November 2017 di Sekolah Dasar Negeri Kuala Bubon Kacamatan Samatiga Kabupaten Aceh Barat.

\section{Metode Pelaksanaan}

Pelaksanaan sosialisasi dimaksudkan sebagai upaya memberikan informasi dan pengetahuan terhadap sesuatu hal. Bentuk sosialisasi yang dilakukan adalah dengan melakukan pemaparan (ceramah) Gemarikan yang selanjutnya dilanjutkan dengan diskusi, tanya jawab dan game.

\section{HASIL DAN PEMBAHASAN Persiapan sosialisasi}

Mengunjungi sekolah dasar negeri (SDN) di Aceh Barat untuk berkoordinasi dan meminta izin pelaksanaan sosialisasi Gemarikan. Pihak sekolah memberikan izin dan akan membantu dalam bentuk menyediakan tempat sosialisasi dan mengarahkan siswa (murid) untuk mengikuti sosialisasi. Tempat sosialisasi di ruang kelas dan menggunakan alat bantu berupa media laptop dan proyektor (infokus) dalam pemaparan materi.
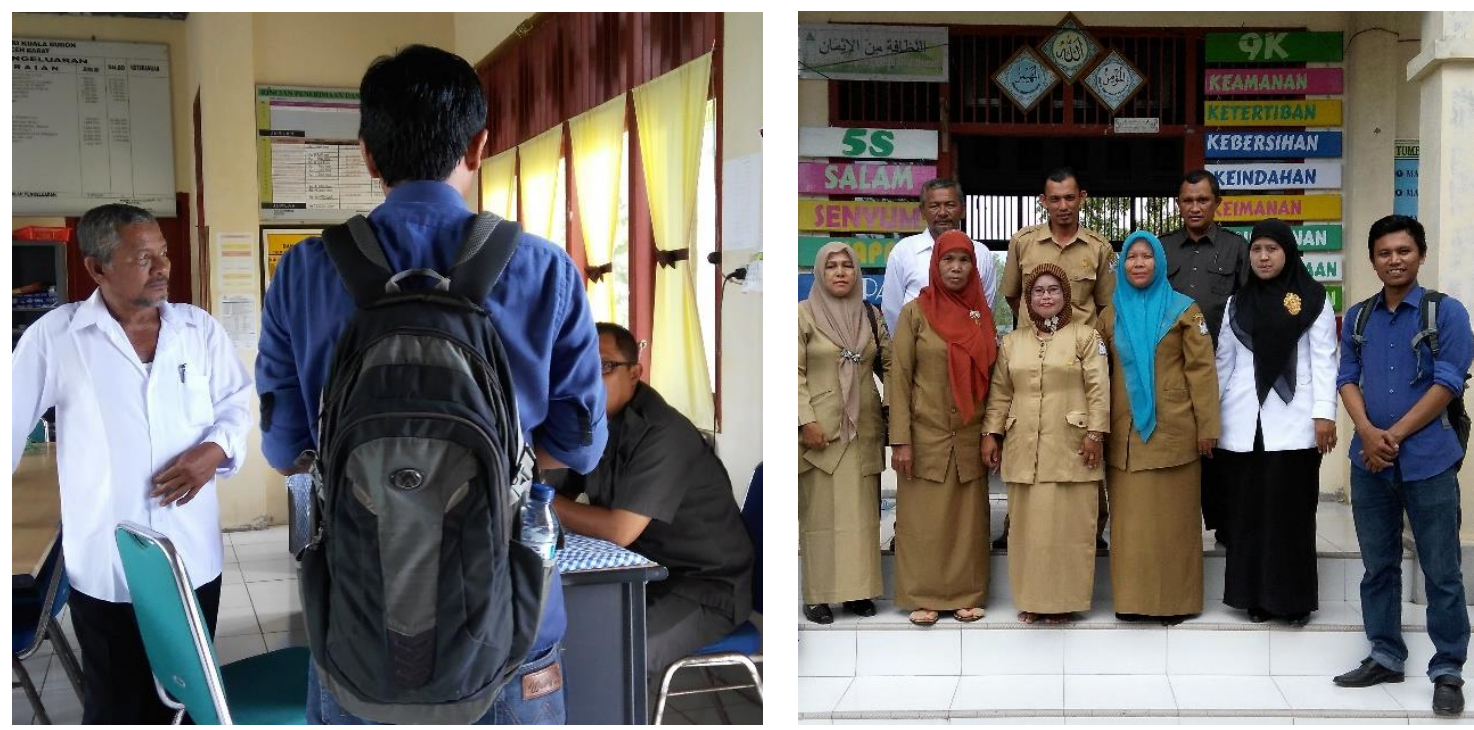

Gambar 1. Koordinasi dengan Kepala Sekolah dan Guru SDN Kuala Bubon

\section{Pelaksanaan sosialisasi}

Peserta sosialisasi adalah siswa (murid) sekolah dasar dan didampingi oleh beberapa guru. Materi yang disampaikan tentang jenis-jenis ikan konsumsi, manfaat dan pentingnya kosumsi ikan, tip memilih ikan segar dan produk-produk olahan perikanan. Materi dipaparkan di layar proyektor dan setiap slide power point di lampirkan animasi/gambar bergerak yang berhubungan dengan materi agar siswa tertarik untuk memperhatikan dan mendegarkan apa yang disampaikan. Cara ini dinilai 
efektif dan berhasil, terlihat dari siswa yang aktif bertanya, dan video juga ditayangkan. Edukasi menyenangkan di terapkan ke siswa dengan bermain game ikan.
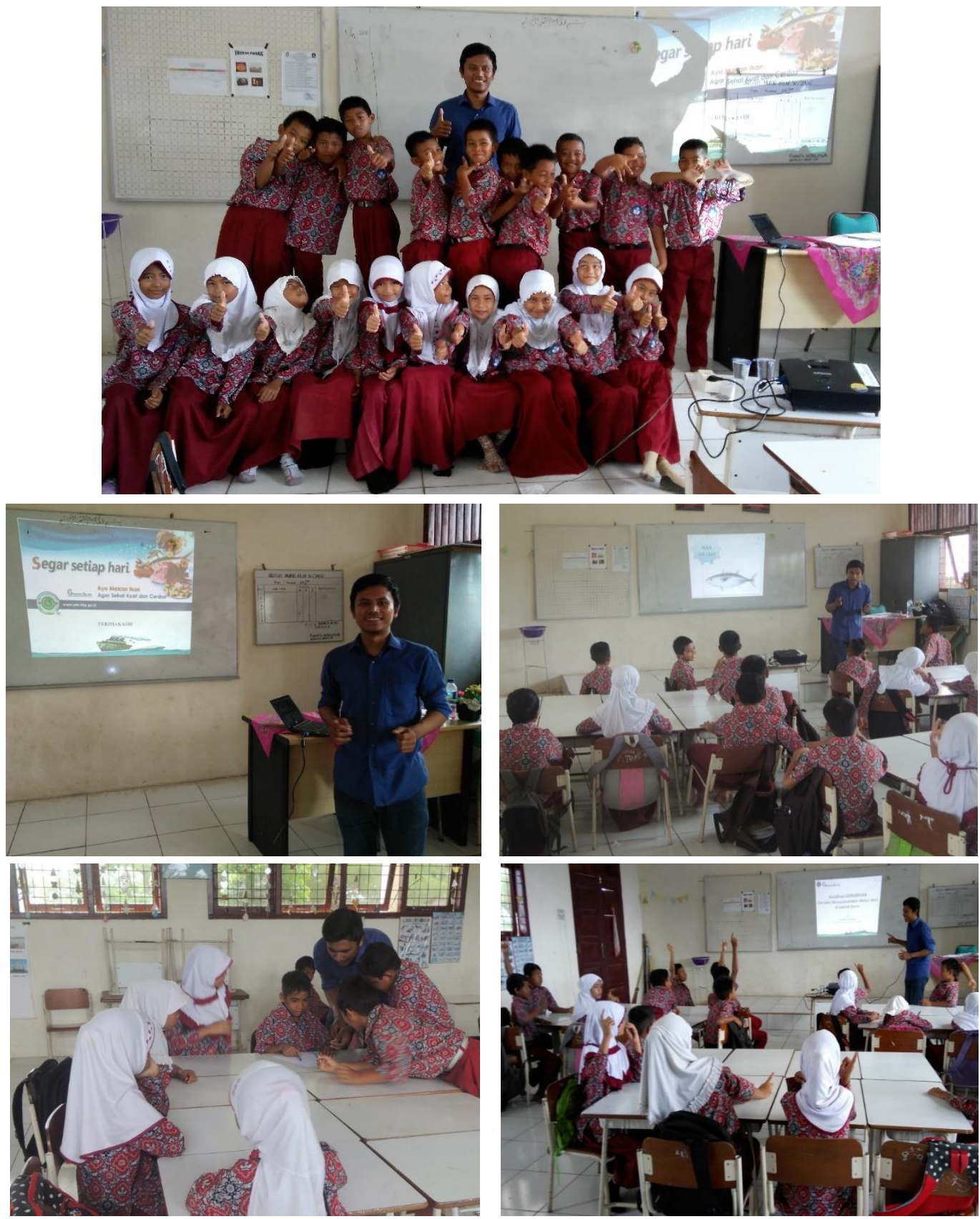

Gambar 2. Sosialisasi Gemarikan dan keaktifan siswa

\section{PENUTUP}

Sosialisasi Gemarikan telah dilaksanakan di sekolah dasar dan siswa mengetahui kandungan gizi dan manfaat mengkonsumsi ikan segar. Diharapkan setelah sosialisasi siswa semakin gemar mengkonsumsi ikan. 


\section{UCAPAN TERIMAKASIH}

Ucapan terimakasih diberikan kepada pimpinan Fakultas Perikanan dan IImu Kelautan Universitas Teuku Umar dan Kepala Sekolah Dasar Negeri Kuala Bubon atas pengurusan administrasi dan izin pelaksanaan sosialisasi.

\section{DAFTAR PUSTAKA}

Detik.com. 2017. https://finance.detik.com/berita-ekonomi-bisnis/d-3500480/konsumsiikan-orang-ri-rendah-di-bawah-malaysia-dan-singapura (diakses: Februari 2018).

Devore. 2009. Dietary intake of fish and omega-3 fatty acids in relation to long-term dementia risk. American Journal Clinical Nutrition, 90, 170-6.

Nilawati, N.S., S.A. Nugraheni dan Frieda N.R.H. 2006. Hubungan Konsumsi lkan Dengan Perkembangan Kognisi Anak Baduta (12-23 Bulan) Studi Di Kecamatan Gandus Kota Palembang Tahun 2006. Jurnal Psikologi Fakultas Psikologi Universitas Gadjah Mada. 33(2). 1 -12. 